\section{SPRU}

Science and Technology

Policy Research
Working Paper Series SWPS 2013-05

September, 2013

\title{
Institutional Voids or Entry Barriers? Business Groups, Innovation and Market Development in Emerging Economies
}

Fulvio Castellacci 


\title{
SPRU Working Paper Series
}

The SPRU Electronic Working Paper Series aims to accelerate the public availability of the research undertaken by SPRU-associated people of all categories, and exceptionally, other research that is of considerable interest within SPRU. It presents research results that in whole or part are suitable for submission to a refereed journal, to a sponsor, to a major conference or to the editor of a book. Our intention is to provide access to early copies of SPRU research.

\section{Editors}

Tommaso Ciarli

Daniele Rotolo

Associate Editors
Florian Kern
Paul Nightingale
Matias Ramirez
Joe Tidd \&
Carlos Sato
Maria Savona \&
Mariana Mazzucato

Andrew Stirling

Area

Energy
Transitions

Science, \& Technology Policy

Development

Technology Innovation Management

Economics of Technological Change

\section{Administrator}

Jenny Lieu

\author{
J.Lieu@sussex.ac.uk
}

M.Savona@sussex.ac.uk

M.Mazzucato@sussex.ac.uk

A.C.Stirling@sussex.ac.uk

\section{Contact \\ T.Ciarli@sussex.ac.uk \\ D.Rotolo@sussex.ac.uk}

F.Kern@sussex.ac.uk

P.Nightingale@sussex.ac.uk

Matias.Ramirez@sussex.ac.uk

J.Tidd@sussex.ac.uk

C.E.Y.Sato@sussex.ac.uk

uk

(1)

(1)

(1)

\section{Disclaimer}

The works available here are the responsibility of the individual author(s) and do not necessarily represent the views of other SPRU researchers. As matters of policy and practice, SPRU does not endorse individual research contributions.

\section{Guidelines for authors}

Papers shall be submitted in pdf or Word format. They should contain a title, an abstract, and keywords. Papers should be submitted to one of the Editors, who will process them and send them to the appropriate Associate Editor. Two members of SPRU will be asked to provide a short written review within three weeks. The revised versions of the paper, together with a reply to the reviewers, should be sent to the Associate Editor, who will propose to the Editors its publication on the series. When submitting the authors should indicate if the paper has already undergone peerreviewing, in which case the Associate Editors may decide to skip internal review process.

\section{Website}

SWPS: www.sussex.ac.uk/spru/research/sewps

IDEAS: ideas.repec.org/s/sru/ssewps.html 


\title{
Institutional Voids or Entry Barriers? Business Groups, Innovation and Market Development in Emerging Economies
}

\author{
Fulvio Castellacci \\ Department of International Economics, \\ Norwegian Institute of International Affairs (NUPI), \\ P0B 8159, Dep. 0033 Oslo, Norway \\ E-mail address: fc@nupi.no \\ Phone: +47-22994040
}

This version: 26 March 2013

\begin{abstract}
The paper presents an empirical analysis of the innovative activities of business groups. It compares the innovativeness of group-affiliated firms (GAFs) and standalone firms (SAFs), and it investigates how country-specific institutional factors - financial, legal, and labor market institutions - affect the group-innovation relationship. The paper outlines two competing views, the institutional voids and the entry barriers theses, and analyses their contrasting predictions on the role of institutional and market development. The empirical analysis is based on the most recent wave of the World Bank Enterprise Survey (period 2010-2011), and it focuses on a sample of 6500 manufacturing firms across 20 Latin American countries. The econometric results point out that GAFs are on average more innovative than SAFs. Across countries, the superior innovation performance of GAFs is stronger for national economies with weaker legal institutions (as predicted by the institutional voids thesis), and for countries with more efficient labor market regulations (as postulated by the entry barriers thesis).
\end{abstract}

Keywords: Business groups; innovation; institutional voids; entry barriers; market development; emerging economies; Latin America 


\section{Introduction}

Business groups permeate emerging economies, often accounting for a substantial share of value added and employment. A business group can be defined as 'a set of firms which though legally independent, are bound together by a constellation of formal and informal ties and are accustomed to taking coordinated action' (Khanna and Rivkin, 2001: 47).

The existence, ubiquity and remarkable dynamics of business groups in emerging markets has stimulated a large amount of research, which has investigated a number of related topics such as the reasons for the emergence of groups, their ownership structure, their differentiation and vertical integration patterns, and their economic performance (Khanna and Yafeh, 2007; Colpan et al., 2010). The existing literature provides a rich and thorough characterization of business groups and their importance for economic development. However, while there exist several studies focusing on the financial and economic performance of groups, much less is known about their strategies, i.e. how groups organize their business activities and what makes them more (or less) successful than independent enterprises (Carney et al., 2011).

One important organizational strategy that deserves closer attention is innovation. The study of innovative activities of business groups is particularly important in the context of emerging economies. A crucial challenge for the catch up process of developing countries is to shift from an imitation to an innovation stage of development (Castellacci and Natera, 2013). What is the role of business groups for technological and economic catch up - do they facilitate this process by enhancing the innovative level of emerging economies, or hamper it by creating entry barriers and inefficiencies in the domestic market? A few recent studies have raised this question, and provided empirical evidence suggesting that GAFs are on average more innovative than SAFs. This is due, among other factors, to business groups' greater access to financial and human capital resources, as well as their ability to take advantage of within-group and foreign spillovers (Mahmood and Mitchell, 2004; Mahmood and Lee, 2004; Mahmood et al., 2011).

In the context of emerging economies, a key question to investigate is how the positive relationship between group affiliation and innovation varies across countries. Many developing economies are currently undergoing a process of institutional change and transition that is commonly referred to as market development (Cuervo-Cazzura and Dau, 2009). How does this process of institutional change and market development affect the relationship between group affiliation and innovation - do GAFs increase or decrease their innovativeness vis-à-vis SAFs when national institutions become stronger and more efficient?

The present paper investigates this question. From a theoretical point of view, there exist two competing views providing different answers to this question. On the one hand, the institutional voids thesis argues that business groups, by making up for the lack 
of well-functioning institutions, tend to perform better and be more innovative in countries with weaker and less efficient institutional set ups (Chang et al., 2006; Mahmood et al., 2011). On the other hand, a different standpoint, which this paper will name the entry barriers thesis, does instead postulate that group affiliation is more beneficial and enhances firm-level innovation relatively more in economies in which national institutions are stronger and more efficient (Chari and David, 2012). This thesis has not been explicitly formulated yet in the literature, and it will be developed in this article.

The objective of this work is precisely to contrast these two theses, point out the main theoretical arguments in favor of one and the other, and carry out an empirical test of their validity in a broad cross-country sample of emerging economies. The paper analyzes, in particular, whether the availability of good financial infrastructure, legal institutions and labor markets regulations decreases the innovativeness of GAFs relatively to SAFs, as predicted by the institutional voids thesis, or rather increases it as postulated by the entry barriers view.

The empirical analysis makes use of the most recent wave of the World Bank Enterprise Surveys (WBES) database, referring to the period 2010-2011. The WBES is a rich and extensive survey dataset of several thousand business firms in developing countries, providing information on their characteristics, strategies, economic performance, as well as their perceptions of the institutional, policy and economic environment in which they operate. A key characteristic of the WBES dataset is that it contains information on firms' ownership, so that we are able to identify which firms in the database that are part of a domestic group, and distinguish these from the group of standalone firms.

Our study focuses on a sample of around 6500 manufacturing enterprises in 20 countries in Latin America. The topic of business groups' innovation activities and their relationships to national institutional conditions is highly relevant for emerging economies in Latin America (Schneider, 2009). During the last two decades, many Latin American economies have undertaken extensive institutional changes and economic reforms - such as privatizations, trade liberalization, financial and macroeconomic stabilization - intended to make domestic markets more open, competitive and efficient. The new competitive environment opens up new challenges and opportunities for domestic firms in the region, and it is thus important to study how business groups are responding to the changing economic environment, and the extent to which their strategies and performance differ from those of standalone enterprises.

On the whole, the paper contributes to the literature along three main dimensions. First, we provide new evidence and quantitative analysis of business groups strategies and innovation activities. In line with the few recent studies on this topic, we find that GAFs are more innovative than SAFs, and we estimate the innovation propensity of GAFs to be $9 \%$ higher than that of SAFs. 
Secondly, our results indicate that both the institutional voids thesis and the entry barriers view receive empirical support, and hence it is not possible to conclude in favor of one of them only and rejecting the other. Specifically, we find that, across countries in Latin America, the superior innovation performance of GAFs is stronger for national economies with weaker legal institutions (as predicted by the institutional voids thesis), and for countries with more efficient labor market regulations (as postulated by the entry barriers thesis). The results for financial institutions are mixed, indicating that in general better access to finance decreases the innovativeness of GAFs vis-à-vis SAFs; however, the availability of equity finance through the stock market may instead strengthen the innovation performance of affiliated companies. On the whole, these findings do not provide a conclusive answer to the question of how the relationship between group affiliation and innovation varies across countries, and call for further research in the future.

Finally, by making use of the extensive set of firm-level information available in the WBES database, our paper suggests a new avenue for empirical analyses in the field. We show that this dataset can be used to compare business groups' characteristics, strategies and performance for several thousand firms across the whole developing world. The results presented in this paper, therefore, can be replicated and extended in future research on business groups in emerging economies.

\section{Business groups in Latin America}

Business groups have for a long time been dominant players in Latin American economies. They are typically large, family-owned, hierarchically controlled and diversified. They account for a large share of value added and employment in many countries in the region. Schneider (2009) points out business groups as a key dimension of the Latin American variety of capitalism, which he defines as hierarchical market economies. Hierarchical market economies in Latin America, a hybrid type between the two standard categories of liberal market economies and coordinated market economies (Hall and Soskice, 2001), are in particular sustained by four main pillars (Schneider, 2009): (1) the relevance of diversified business groups, (2) a high-presence of multinational corporations, (3) low-skilled labor, (4) atomistic labor relations coupled with extensive, and often inefficient, labor market regulations (Botero et al., 2004). These four characteristics are closely intertwined and tend to reinforce each other: it is these institutional complementarities that explain why business groups constitute a structural and long-standing feature of this region.

Despite their importance, empirical data and evidence on business groups in Latin America is scant and far more limited than it is the case for other emerging economies (e.g. in East Asia). Chile is the economy in the region with a relatively better availability of information on business groups' strategies and performance. Khanna and Palepu (2000) used this information to study the relationship between diversification and the financial performance of groups in Chile in the period 1988-1996. Khanna and Rivkin 
(2006) analyzed the relationships between interorganizational ties, family ownership and business groups. Another important work on Chile was presented by Khanna and Palepu (1999), which investigated the evolution of 18 large and diversified groups in the period 1987-1997, and showed that deregulation and other economic reforms in this decade did not have a negative effect on the performance of domestic business groups, as one would expect, but they rather contributed to strengthen their market dominance. More recently, other historically-oriented studies have provided new information and an updated overview of the long-run evolution of business groups in other Latin American countries: Argentina (Fracchia et al., 2010), Brazil (Aldrighi and Postali, 2010), Mexico (Hoshino, 2010) and Central American countries (Bull and Kasahara, 2012).

On the whole, empirical evidence on business groups in Latin America is still limited and far less extensive than it is the case for other emerging economies. Most of the existing studies are descriptive in nature and do not provide insights on how the performance of business groups is affected by group-specific characteristics and strategies, such as ownership, diversification, internationalization and technological innovation. The latter is an increasingly important factor for catching up countries in the region (Castellacci and Archibugi, 2008; Castellacci, 2011), and it is therefore important to investigate business groups' capabilities and technological performance.

Further, the literature on business groups in Latin America identifies some important patterns in relation to the changing institutional context in the region. In most cases, groups originated several decades ago, and their initial formation and growth was closely linked and actively supported by public policies, such as State-led industrialization strategies, public ownership, trade protection and public procurement. Business groups have traditionally had close ties to national governments and often a strong political influence on them. The extensive process of economic reforms that was undertaken in many countries in the region during the 1980s and 1990s privatizations, trade liberalization, financial and macroeconomic stabilization - does not seem to have negatively affected groups more than other firms. Business groups did actually grow stronger and found new strategies to survive in the new highly competitive environment. These findings do on the whole challenge the conventional view that business groups perform better in less developed institutional contexts. They thus call for a reassessment of the institutional voids thesis for the case of Latin America.

\section{Theory}

The study of innovative activities of business groups is particularly important in the context of emerging economies. A crucial challenge for the catch up process of developing countries is to shift from an imitation to an innovation stage of development (Castellacci and Natera, 2013). What is the role of business groups for technological and economic catch up - do they facilitate this process by enhancing the innovative level of emerging economies, or hamper it by creating entry barriers and inefficiencies in the domestic market? 
A few studies have recently extended the business groups literature to analyze whether group-affiliated firms (GAFs) are more innovative than standalone firms (SAFs) (Mahmood and Mitchell, 2004; Mahmood and Lee, 2004; Chang et al., 2006; Belenzon and Berkovitz, 2010; Mahmood et al., 2011). The empirical results of these works all point to a positive impact of group affiliation on innovation, due to the following channels.

First, GAFs can more easily get access to financial capital within the group when external financial markets are inefficient, and hence also reduce the uncertainties related to $R \& D$ investments. Secondly, when the country has a low level of human capital and workers' skills, GAFs may provide workers with training and more efficiently allocate labor resources internally within the group. Thirdly, when the home market is not well developed, GAFs may overcome the lack of independent suppliers and advanced users by linking to other firms of the same (vertically-integrated) group. ${ }^{1}$ Hence, vertical integration may partly substitute for the lack of a good home market. Relatedly, GAFs may have greater access to internal information and advanced knowledge (within-group spillovers). Fourthly, due to their established market position and distribution network, GAFs are in a better position to develop collaborations with foreign firms and MNEs, so possibly exploiting knowledge imitation and foreign spillovers.

In the context of emerging economies, a key question to investigate is how this positive relationship between group affiliation and innovation varies across countries. Many developing economies are currently undergoing a process of institutional change and transition that is commonly referred to as market development (Cuervo-Cazzura and Dau, 2009). Following (Chakrabarti et al., 2011: 7), this may be defined as "the degree to which market-oriented institutions such as capital markets, legal systems, labor markets, and commercial value chains are present in support of business activity". How does this process of institutional change and market development affect the relationship between group affiliation and innovation - do GAFs increase their innovativeness vis-àvis SAFs when national institutions become stronger and more efficient?

This question is not only important from a comparative institutional perspective. In more general terms, as observed by Chang et al. (2006), innovation studies have not yet achieved a clear understanding of how firm-level strategies and innovative activities interact with the macro environment in which they operate. While management studies do in general focus on firm-level resources, capabilities and strategies, the innovation system literature points out that firms' innovation investments are highly dependent upon, and supported by, country-level institutions (Nelson, 1993). In particular, financial institutions favor private firms' access to finance, making available resources to invest in R\&D; legal institutions and an efficient court system favor commercial

\footnotetext{
${ }^{1}$ Mahmood et al. (2011) point out in particular that intra-group ties are important for the capability formation and R\&D activities of business groups, and that it is important to distinguish the effect of three types of ties: buyer-supplier, equity and director ties.
} 
transactions, contract enforcing and the protection of intellectual property rights (IPRs); and labor market regulations affect the pool of human resources that a company can draw from, or determine the flexibility of the labor market and hence the ability of firms to hire new workers. It is therefore crucial to investigate further the process of interaction between the micro- and macro-level in innovation studies, and how this coevolves with institutional and economic development.

The question of the relationship between group affiliation and innovation, and how this is affected by country-level institutions, does not have a clear cut answer. From a theoretical point of view, there exist two competing arguments. The first is the so-called institutional voids thesis, according to which business groups, by making up for the lack of well-functioning institutions, tend to perform better and be more innovative in countries with weaker and less efficient institutional set ups. Most recent studies on this question have adopted this thesis (Chang et al., 2006; Mahmood et al., 2011). By contrast, a different standpoint, which this paper will name the entry barrier thesis, does instead argue that group affiliation may be more beneficial and enhance firm-level innovation in economies in which national institutions are stronger and more efficient. This thesis has not been explicitly formulated yet in the literature, and it will be developed in this article.

The contribution of this work is precisely to contrast these two theses, point out the main theoretical arguments in favor of one and the other, and carry out an empirical test of their validity in a broad sample of emerging economies in Latin America. The motivation for undertaking this type of exercise is well illustrated by Carney et al (2011), which, in a recent comprehensive overview of the literature, concluded that: "We see a need for future studies offering concurrent tests of multiple theories, as well as studies developing and testing eclectic explanatory frameworks combining variables from multiple-source theories" (Carney et al., 2011: 452). Table 1 summarizes the main arguments of these two theses. 
Table 1: Theoretical framework - Two competing views on group affiliation and innovation

\begin{tabular}{|c|c|c|}
\hline & Institutional voids thesis & Entry barriers thesis \\
\hline $\begin{array}{l}\text { Role of business } \\
\text { groups } \\
\text { in emerging } \\
\text { economies }\end{array}$ & $\begin{array}{l}\text { Paragons: } \\
\text { Groups fill in institutional voids, } \\
\text { thus playing an important role for } \\
\text { economic development }\end{array}$ & $\begin{array}{c}\text { Parasites: } \\
\text { Groups create entry barriers and reduce } \\
\text { heterogeneity; they are rent-seeking } \\
\text { organizations with close ties to public } \\
\text { authorities }\end{array}$ \\
\hline $\begin{array}{l}\text { Theoretical } \\
\text { framework }\end{array}$ & $\begin{array}{l}\text { Transaction costs economics; } \\
\text { Resource-based view of the firm }\end{array}$ & $\begin{array}{c}\text { Evolutionary economics; } \\
\text { Agency theory and corporate } \\
\text { governance }\end{array}$ \\
\hline $\begin{array}{l}\text { Changing role of } \\
\text { groups } \\
\text { over time }\end{array}$ & $\begin{array}{l}\text { When institutions develop and become } \\
\text { more efficient, } \\
\text { the source of groups' superiority } \\
\text { decreases, } \\
\text { and their advantage over SAFs is eroded }\end{array}$ & $\begin{array}{l}\text { When institutions develop and become } \\
\text { more efficient, } \\
\text { groups become more innovative, better } \\
\text { organized } \\
\text { and better able to reap external sources } \\
\text { of opportunity }\end{array}$ \\
\hline $\begin{array}{l}\text { Cross-country } \\
\text { pattern }\end{array}$ & $\begin{array}{c}\text { Across countries, } \\
\text { the difference between the } \\
\text { innovativeness of GAFs and SAFs is } \\
\text { stronger in countries with weaker and } \\
\text { less efficient institutions }\end{array}$ & $\begin{array}{c}\text { Across countries, } \\
\text { the difference between the } \\
\text { innovativeness of GAFs and SAFs is } \\
\text { stronger in countries with better and } \\
\text { more efficient institutions }\end{array}$ \\
\hline
\end{tabular}

\section{The institutional voids thesis}

According to this thesis, business groups in emerging economies are paragons: they play an important function for economic development by making up for missing or inefficient institutions, hence filling institutional voids (Leff, 1978; Khanna and Palepu, 1997). Thus, groups originate and prosper when national institutions are weak and, correspondingly, group performance is relatively better in countries characterized by weaker institutions than in economies with well-functioning institutional set ups (Khanna and Yafeh, 2007; Carney et al., 2011).

The theoretical arguments that provide a conceptual foundation to this market failure view are primarily rooted in transaction costs economics (Williamson, 1975): taking advantage of their organizational structure and internal network, groups may decrease and partly avoid the high transaction costs that characterize the inefficient market context that is typical of less developed economies. Further, this argument of the superior performance of groups in emerging economies is also related to the resourcebased view of the firm (Penrose, 1959; Wernerfelt, 1984). According to this, it is important to distinguish between resources and capabilities: the former are stocks of production factors that a firm possesses (e.g. physical and human capital), whereas the latter represent its ability to manage these resources in order to create products and services. According to Guillen (2000), the resource-based view may explain why 
business groups are more prevalent in economies in which managers and companies are able to accumulate the capability and resources for repeated industry entry. ${ }^{2}$

The institutional voids thesis has recently been extended to the study of business groups' innovative activities (Mahmood and Mitchell, 2004; Chang et al., 2006; Mahmood et al., 2012). The main argument here is that groups provide innovation infrastructures in emerging markets when financial, legal and labor market institutions are weak. Hence, the positive effects of group affiliation on innovation are more relevant in less developed economies, in which groups make up for market failures and institutional weaknesses. In particular, with respect to financial institutions, group affiliation may be a way to get access to financial capital for innovative activities when financial markets and credit institutions are not efficient. Groups may also make up for the lack of legal institutions and weak contract enforcement mechanisms, thus making it possible to decrease transaction costs in product and factor markets. Further, if labor markets are inefficient and rigid, group affiliation may enable to get access to qualified human capital or set up training courses internally within the group, thus sustaining further the innovative activities of GAFs.

This thesis does also imply that, when an emerging economy undertakes a process of institutional transition and market development, national institutions will gradually become more efficient, and hence the source of GAFs superiority over SAFs will progressively decrease. Therefore, during a development process in which institutional transition brings a reduction in transaction costs, it is possible to expect that smaller and unaffiliated firms will increase their technological capabilities vis-à-vis larger and well established business groups, eventually leading to a more competitive and less concentrated market.

Among the key studies developing this view, Chang et al. (2006) provide empirical evidence on the greater innovation performance of group affiliated firms in emerging economies by carrying out a comparison of groups in Korea and Taiwan. Mahmood and Mitchell (2004) present an industry-level study pointing out the existence of an inverse U-shaped relationship between the presence of groups within an industry and the sector's innovativeness. Consistently with the institutional voids thesis, this study also shows that the threshold at which the marginal costs of group affiliation become greater than the corresponding benefits is lower for more advanced economies. Further, Mahmood et al. (2012) extend previous studies by focusing on the effects of intra-group buyer-supplier ties on groups' innovativeness. The work argues that intra-group ties have two offsetting effects on innovation: they create combinatorial opportunities that

\footnotetext{
${ }^{2}$ Foss and Foss (2005) discuss the complementarities between transaction costs economics and the resourcebased view of the firm. The main insight is that companies, in order to create value, must not only be able to manage their resources and capabilities in an efficient way, but should also try to appropriate the benefits of their production activities through property rights or the ability to cope with transaction costs. For the study of business groups, this means that group affiliation has a positive effect on firm performance because it enables to reduce transaction costs and hence appropriate resources that represent the competitive advantage of the firm.
} 
support knowledge sharing and innovation, but at the same time may also lead to combinatorial exhaustion that constraints innovation after a certain threshold level of intra-group ties density. This study also finds, in line with previous works, that this threshold level is more rapidly met in countries with more developed market institutions, i.e. the benefits of group affiliation are relatively weaker in a more developed market.

While these seminal works have the important merit of having opened a brand new direction of research in the business groups literature, the empirical evidence upon which their results are based is mostly focused on Taiwan, Singapore, Korea and a few other East Asian economies. Do the same results hold for different geographical areas than East Asia, or for a broader cross-country sample of emerging economies? Previous cross-country comparisons, focused on group performance in general rather than innovation, provide a mixed and inconclusive answer to this question. Khanna and Rivkin (2001) present a cross-country analysis of 14 emerging markets, indicating that group affiliation is actually more profitable in countries with a better availability of financial infrastructures, including four of the major Latin American economies (Mexico, Chile, Brazil and Argentina). Khanna and Yafeh (2005) carry out a cross-country test of the institutional voids thesis, reporting no significant correlation between countries' quality of legal and financial institutions and business groups' extent and performance. Finally, Carney et al. (2011) present a comprehensive meta-analysis of a large number of studies of business groups and affiliate performance, and find that institutional voids in the legal dimension are actually negatively related to the performance of GAFs. Such cross-country patterns cannot easily be reconciled with the predictions of the institutional voids thesis. It is therefore important to discuss a second theoretical view, according to which market development and institutional transitions would not necessarily decrease the superiority of groups but they may actually even turn out to increase it.

\section{The entry barriers thesis}

A different view argues that business groups are parasites for developing economies. They are strong oligopolistic producers that are capable of erecting entry barriers. They are also inefficient and rent-seeking organizations that create agency problems and capital misallocations. According to this second thesis, these group-related inefficiencies would tend to decrease when the quality of institutions improves over the development process. Therefore, differently from the institutional voids view, the entry barriers thesis would expect group performance and innovative capabilities to be relatively better in countries characterized by well-functioning institutions than in economies with weaker institutional set ups.

The entry barrier thesis is founded upon two types of theoretical arguments. The first is related to the evolutionary economics perspective (Nelson and Winter, 1982; Hannan 
and Freeman, 1989; Nelson, 1995). ${ }^{3}$ According to an evolutionary logic, groups create entry barriers in order to protect their market dominance, and may in this way reduce heterogeneity and hamper the entry of new innovative firms in the market (Mahmood and Mitchell, 2004). This approach also emphasizes that the process of technology and capability imitation is costly and difficult, and so cumulativeness and persistence are often important features characterizing market dynamics. Hence, when a process of institutional change and transition is in place, this may actually lead to a further strengthening of the dominant position of larger and well-established GAFs vis-a-vis smaller and less competitive unaffiliated companies. Three specific arguments corroborate this view.

First, as observed by Fortune and Mitchell (2012), when a national market becomes more open and competitive, the evolutionary process of selection becomes stronger: smaller and less competitive firms are driven out of the market (dissolution), whereas other companies are acquired by larger establishments or groups (acquisition). Hence, larger firms and groups will grow by acquiring other domestic companies, and may in this way strengthen their capability pool and innovative potential vis- $a$-vis other smaller unaffiliated companies. In other words, as market develops and institutions become more efficient, business groups will undergo a process of adaptation whereas SAFs are more likely to experience selection.

Another related mechanism is pointed out by Chakrabarti et al. (2011), which study the distinction between growth and retrenchment as two distinct strategies of asset reconfiguration. During a process of market reform, it is in general more likely that stronger firms will follow a growth strategy, whereas weaker companies will undertake a retrenchment strategy. Chakrabarti et al. (2011) also show that in stronger and more efficient institutional environments, the growth strategy will tend to be more effective than the retrenchment strategy. This general argument may have specific implications for the dynamics of business groups. If better performing companies are more likely to belong to, or be acquired by, business groups during institutional transition, affiliated firms would arguably strengthen their market position by following a growth strategy, thus increasing further their superiority vis-à-vis unaffiliated companies.

Thirdly, recent developments in the competition and innovation literature in industrial economics further corroborate these arguments. In particular, Aghion et al. (2005) argue that product market competition boosts R\&D investments, since it may increase the incremental profits that firms obtain by investing in $R \& D$ activities. This argument, so-called escape-competition effect, points out that the relationship between the degree of market competition and innovation may hence be positive, and even more so in neckto-neck industries where competition between rival firms is fierce. This general argument may again have specific implications for the business groups literature. Group

\footnotetext{
${ }^{3}$ For a survey of the theoretical foundations and recent developments of evolutionary economics, see Castellacci (2007).
} 
affiliates, when faced with market liberalization and a higher degree of competition, may actually increase their innovative efforts in order to stay ahead of their competitors.

In addition to these arguments related to evolutionary economics, there is also another theoretical view that is consistent with the entry barriers thesis: agency theory and corporate governance (Morck et al., 2005). According to this approach, groups have often concentrated ownership characterized as control pyramids, in which a family firm controls several listed companies. This type of structure leads to the separation of ownership and control and thereby creates important agency problems. One is entrenchment, meaning that the controlling owner has a privileged and protected position within the group. Another is the divergence of interests between majority and minority shareholders, which makes it possible for the former to achieve private benefits of control. A third type of agency problem is tunneling, in which value may be transferred from one pyramid firm to another. The effects of these agency problems are capital misallocations and depressed investments in innovation. Specifically, Morck et al. (2005) point out the so-called creative self-destruction effect: since the innovation produced by one GAF may be competing with, and have negative effects on, the other companies affiliated to the same group, for the group as a whole the incentives to invest in innovation are reduced.

From an agency theory and corporate governance perspective, institutional improvements would then decrease the scope for the agency problems related to control pyramids, and even turn out to make groups more efficient and innovative. Fogel (2006) shows that in countries with weaker institutional set ups family control and rentseeking activities of groups are more common. This would imply that, when a country evolves and improves its institutions, groups have to adjust their organizational structure and strategy, thus becoming more dynamic and innovative.

A related argument is that groups are rent-seeking organizations with close ties to public authorities (La Porta et al., 1999; Rajan and Zingales, 2003). Khanna and Yafeh (2007: 352) emphasize that "business groups are formed with government support, expand and diversify with government nurturing, and their performance is a function of their rent-seeking ability and opportunities". Chung et al. (2007) point out that, when a process of institutional change and transition takes place, political connections change form - shifting from formal ties to main political authorities towards more informal connections to a multitude of different actors - but they still continue to be an important channel through which groups defend their interests and pursue rent-seeking activities.

On the whole, the main implication of the corporate governance perspective is consistent with the evolutionary economics arguments discussed above. When institutions develop and become more efficient, groups may become more competitive, better organized and better able to reap external sources of opportunity and policy incentives. Chari and David (2012) find that Indian groups, after the process of market reforms, have indeed strengthened their core competencies and invested more in $R \& D$, 
thus increasing their competitive position. The historical evidence on the long-run evolution of groups in Latin America briefly discussed in the previous section points in the same direction.

\section{Hypotheses}

The institutional voids and the entry barriers theses provide different answers to the question on whether group affiliation spurs innovation relatively more in economies characterized by weaker and inefficient institutions, or rather in countries with a better institutional quality. The main prediction of the institutional voids thesis is that the difference between the innovativeness of GAFs and SAFs is greater in economies with weaker and less efficient institutions, since it is in this type of national contexts that group affiliation makes it possible to reduce transaction costs and make up for the lack of institutions supporting an open and competitive market.

By contrast, the entry barrier thesis leads to the opposite prediction: the difference between the innovativeness of GAFs and SAFs is likely to be greater in economies with a better institutional quality. The reason is twofold. First, from an evolutionary economics perspective, groups are likely to strengthen their capability pool and have greater incentives to innovate when institutions become more efficient and the market gets more competitive. Secondly, from a corporate governance standpoint, institutional developments do also contribute to alleviate the inefficiencies and agency problems related to group pyramidal structure and rent-seeking activities, thus making groups more efficient and more innovative organizations.

These general conjectures on the role of institutions for group innovativeness lead to the formulation of three more specific hypotheses, focusing on the role of financial, legal and labor market institutions respectively. These are in fact the three main institutional domains that are typically considered in the business group literature and in comparative institutional analyses (Botero et al., 2004; Khanna and Yafh, 2007; Carney et al., 2011).

\section{Financial institutions}

According to the institutional voids thesis, groups provide innovation infrastructures in emerging markets when institutions are weak. In particular, group affiliation may be a way to get access to financial capital for innovative activities when financial markets and credit institutions are not efficient. Hence, the hypothesis related to this thesis is that GAFs have greater access to financial capital to invest in innovative activities than SAFs particularly in countries with weaker and less efficient institutions.

By contrast, the entry barrier thesis would lead to the opposite prediction: the difference between the innovativeness of GAFs and SAFs may arguably be stronger in countries with better financial institutions. The reason is that during a process of market development, financial institutions become more efficient, providing business firms with 
a broader choice on how to finance their innovative activities. Companies may in particular choose between debt and equity finance. The latter may spur innovation investments because it contributes to lower the risks of uncertain technological activities, and it increases the financial commitment of the enterprise (Lazonick, 2007). If GAFs, thanks to their group affiliation, have a higher facility and propensity to use equity finance than SAFs, this may increase the financial resources that they invest in innovative activities vis-à-vis SAFs.

\section{Hypothesis 1 (financial institutions)}

H1a: Across countries, the difference between the innovativeness of GAFs and SAFS is stronger in countries with weaker and less efficient financial institutions.

H1b: Across countries, the difference between the innovativeness of GAFs and SAFS is stronger in countries with better and more efficient financial institutions.

\section{Legal institutions}

The institutional voids thesis emphasizes the importance of transaction costs, and the related market failures and inefficiencies that these may lead to in product and factor markets. Business groups, thanks to their organizational structure and internal networks, may however make up for the lack of well-functioning legal institutions and partly avoid weak contract enforcement issues, thus making it possible to decrease transaction costs in emerging markets. The cross-country implication of this argument is that group affiliation provides a more important factor spurring innovative activities in countries with weaker and less efficient legal institutions.

On the other hand, the entry barriers thesis would lead to the opposite hypothesis, namely that, the difference between the innovativeness of GAFs and SAFs may turn out to be stronger in countries with a better quality of legal institutions. As pointed out in the previous section, two arguments support this view. First, from an evolutionary economics perspective, it is reasonable to argue that when legal institutions and IPR protection become stronger, groups may benefit relatively more than independent firms because the rents of their innovative activities can more easily be appropriated and reaped. In a more competitive market, GAFs will also have greater incentives to invest in innovation in order to maintain their market leadership (Aghion and Howitt, 2005). Secondly, the corporate governance perspective would argue that, during a process of institutional transition and market development, legal institutions progressively become more protective of the rights of minority shareholders, thus mitigating the agency problems associated with control pyramids and increasing the efficiency and innovativeness of group-affiliated firms. 


\section{Hypothesis 2 (legal institutions)}

H2a: Across countries, the difference between the innovativeness of GAFs and SAFS is stronger in countries with weaker and less efficient legal institutions.

H2b: Across countries, the difference between the innovativeness of GAFs and SAFs is stronger in countries with better and more efficient legal institutions.

\section{Labor market institutions}

In line with the previous two hypotheses, the institutional voids thesis also points out that when labor markets are inefficient, e.g. because of the weak supply of qualified workers and the highly regulated nature of labor institutions, it may be difficult for companies to get access to the qualified human capital they need for undertaking technological activities. In this context, group affiliation may enable to get more easily access to qualified human capital internally within the group, or benefit from training courses for the employees organized by the group itself, compensating for the lack of training programmes in the public education and science system. For this reason, the hypothesis developed by this view is that the difference between the innovativeness of GAFs and SAFs is stronger when countries have weaker and less efficient labor market institutions.

By contrast, the entry barriers thesis would again lead to the opposite expectation: group affiliation is likely to spur innovative investments relatively more in emerging economies characterized by better and more efficient labor market institutions. In fact, when labor markets become more efficient and flexible, it may become easier for GAFs to use this greater institutional flexibility to get rid of less productive workers and attract the most talented managers and employees, thus increasing their human capital level and innovative potential vis-a-vis SAFs. Further, in a labor market where unions have weaker power, employers are in general more prone to undertake and finance training programmes to develop firm-specific skills and capabilities (Belloc, 2012). For both of these reasons, business groups may arguably benefit from labor market liberalization to a greater extent than SAFs.

\section{Hypothesis 3 (labor market institutions)}

H3a: Across countries, the difference between the innovativeness of GAFs and SAFS is stronger in countries with weaker and less efficient labor market institutions

H3b: Across countries, the difference between the innovativeness of GAFs and SAFS is stronger in countries with better and more efficient labor market institutions

Before turning to the empirical analysis, it is important to clarify that the hypotheses tests that we will carry out in the next sections do not aim at showing that one thesis is correct and the other is not. We believe that the arguments put forward by both the institutional voids thesis and the entry barriers view have solid conceptual foundations 
and empirical support in previous research. Our analysis does actually intend to investigate the overall (net) effect of these two competing forces, and point out whether of them prevails over the other in a specific cross-country setting.

\section{Data and indicators}

Our empirical analysis makes use of the World Bank Enterprise Surveys (WBES) database. This is a rich and extensive survey dataset of several thousand business firms in nearly all developing countries, providing information on their characteristics, strategies, economic performance, as well as their perceptions of the institutional, policy and economic environment in which they operate. The WBES follows a stratified random sampling with replacement, based on firm size, business sector and geographic region as the main strata, which ensures representativeness of the results within each country. The survey questionnaire follows a standard template, in order to ensure crosscountry comparability of the results. ${ }^{4}$

We focus on the most recent wave of the WBES, the one referring to the period 20102011. A key characteristic of the WBES dataset does now contain information on firms' ownership. From this information, we are able to identify which firms in the database that are part of a domestic group (GAFs), and distinguish these from the group of standalone firms (SAFs). This information is very valuable from the point of view of the business groups literature. So far, group identification has in fact been a controversial and difficult task for empirical works in this field (Khanna, 2000; Yafeh, 2005), and the information on group affiliation has often been limited to enterprises within a specific country. The present paper, by making use of the new information available in the WBES 2010, suggests a new avenue for empirical analyses in the field, making it possible to compare business group characteristics, strategies and performance for several thousand firms across the whole developing world.

Our study focuses on 20 Latin American countries, covering nearly the whole region. The whole sample contains a total number of around 13000 firms, covering all sectors of economic activity (agriculture, manufacturing and services). However, since one of the variables of our interest, technological innovation, is only available for firms in the manufacturing sector, we eventually narrowed down our sample to a total number of around 6500 enterprises. The empirical analysis makes use of the following indicators.

\section{Firm-level variables}

GAF: Group-affiliated firm. Dummy variable indicating whether an enterprise is part of a domestic group. This indicator has been obtained by interacting (multiplying) two dummy variables of the WBES questionnaire: (1) the one reporting whether "the establishment is part of a larger firm" (question A.7); (2) the one indicating whether "the

\footnotetext{
${ }^{4}$ For a detailed description of the dataset and its methodology, see the WBES page: www.enterprisesurveys.org.
} 
firm is owned by private domestic individuals, companies or organizations". 5 This variable is then able to distinguish two types of enterprises in our sample: domestic group-affiliated firms (GAFs) and domestic standalone firms (SAFs). Table 1 shows that $12,4 \%$ in our sample are GAFs.

INNO: Innovation. Dummy variable indicating whether an enterprise has carried out R\&D investments in the period (question LAC.E6). This is a standard indicator of technological innovation, which is the predominant type of innovation for firms in manufacturing industries. R\&D investments are not only important because they lead to the introduction of brand new products and processes, but also because they increase a firm's capability to imitate external advanced knowledge (Cohen and Levinthal, 1990). The indicator is therefore useful to measure Latin American firms' innovation propensity as well as their imitation ability. On average, $45 \%$ of manufacturing firms in the sample have undertaken R\&D investments in the period. ${ }^{6}$

SIZE: Size of the firm. Categorical indicator taking three possible values: 1 if the firm has between 5 and 20 employees; 2 if it has between 20 and 100 workers; 3 if it has more than 100 employees (question A.6 of the WBES survey). The average firm size category in our sample is 2 (between 20 and 100 workers), and the cross-country variability of this indicator is low: in all of the Latin American countries in the sample, small and medium-sized enterprises constitute the bulk of the business population.

AGE: Age of the enterprise. Number of years since the establishment began operations (question B.5). The variable ranges from 0 to 340 years, and the mean value is approximately 28 years.

QUALITY: Quality certification. Dummy variable indicating whether the firm has "an internationally-recognized quality certification, such as ISO 9000, 9002 or 14000" (question B.8). On average $28 \%$ of enterprises in the sample report to have obtained quality certification.

EDUC: Education level. "Average number of years of education of a typical permanent full-time production worker employed in the establishment" (question L.9a). The mean value in the region is 10 years.

ICT: ICT infrastructure. Dummy variable reporting whether a firm has "a high-speed Internet connection on its premises" (question C.23). A large majority of firms in the sample (87\%) report to have good Internet infrastructure, although the variable differs

\footnotetext{
${ }^{5}$ This second variable has been obtained from question B.2a, assuming that a firm is domestically owned if at least $50 \%$ of its ownership belongs to private domestic individuals, companies or organizations.

${ }^{6}$ In addition to this R\&D variable, we have also used a dummy variable indicating whether the firm has introduced a new product in the period (NEW_PROD). The new product dummy measures the outcome of innovation. It is interesting to use this variable, along with the R\&D dummy, in order to see whether the main patterns investigated in the paper also hold for the innovation performance of firms in addition to their innovation propensity.
} 
substantially across countries - ranging from 95\% in Argentina, Colombia and Ecuador to below 65\% in most Central American countries.

DIVERSIF: Product diversification. Percentage of total sales represented by other products than the firm's main product (question D.1a3). The mean value of this variable in the sample is $30 \%$.

URBAN: Urban density. Indicator reporting the size of the city in which the firm is located. The variable is categorical and takes five possible values: 1 if it is a town with less than 50000 inhabitants; 2 between 50000 and 250000 people; 3 between 250000 and 1 million; 4 if it is a city with population over 1 million, but not a capital city; 5 if it is a capital city. The indicator is obtained from question A.3, and it is used as a proxy for urban density and agglomeration economies.

OBST_FINANCE: Obstacle: Financial system. Variable indicating whether "access to finance - which includes availability and cost, interest rates, fees and collateral requirements - is an obstacle to the current operations of the firm" (question K.30). The variable is categorical, ranging from a value of 0 (no obstacle) to 4 (very severe obstacle).

OBST_LEGAL: Obstacle: Legal system. Variable indicating whether legal courts represent an obstacle to the current operations of the enterprise (question J.30). The variable is categorical, ranging from a value of 0 (no obstacle) to 4 (very severe obstacle).

OBST_LABOR: Obstacle: Labor regulations. Variable indicating whether "labor regulations are an obstacle to the current operations of the firm" (question L.30). The variable is categorical, ranging from a value of 0 (no obstacle) to 4 (very severe obstacle).

\section{Country-level variables}

FINANCE: Access to finance. This is the country average of the firm-level variable OBST_FINANCE defined above. The indicator has been multiplied by - 1, so that a higher value of the variable indicates better access to finance. It is used to test hypothesis 1.

STOCK: Stock market. Stocks traded, \% of GDP (source: World Bank, World Development Indicators). It is used to test hypothesis 1.

LEGAL: Legal institutions: Courts. This is the country average of the firm-level variable OBST_LEGAL defined above. The indicator has been multiplied by - 1 , so that a higher value of the variable indicates better functioning legal courts. The indicator is employed in the test of hypothesis 2 .

TRUST: Legal institutions: Trust. Percentage of respondents who agree with the statement: "Most people can be trusted" (source: World Value Survey). The indicator is employed in the test of hypothesis 2 . 
LABOR: Labor market regulations. This is the country average of the firm-level variable OBST_LABOR defined above. The indicator has been multiplied by -1 , so that a higher value of the variable indicates more efficient labor market regulations. It is used for the test of hypothesis 3 .

TERTIARY: Tertiary education. Tertiary enrolment ratio (source: World Bank, World Development Indicators). It is used for the test of hypothesis 3.

Table 2 presents some descriptive statistics for the firm-level indicators used in this study, and table 3 shows the coefficients of correlation among these variables.

Table 2: Descriptive statistics

\begin{tabular}{|cccccc|}
\hline Variable & Mean & Std. Dev. & Min & Max & obs. \\
GAF & & & & & \\
INNO & 0.124 & 0.329 & 0 & 1 & 6573 \\
SIZE & 0.451 & 0.497 & 0 & 1 & 6573 \\
AGE & 2.004 & 0.809 & 1 & 3 & 6573 \\
QUALITY & 27.84 & 21.34 & 0 & 340 & 6535 \\
EDUC & 0.280 & 0.449 & 0 & 1 & 6263 \\
ICT & 10.33 & 3.95 & 0 & 25 & 6059 \\
DIVERSIF & 0.868 & 0.338 & 0 & 1 & 6401 \\
URBAN & 30.36 & 26.14 & 1 & 100 & 6504 \\
OBST_FINANCE & 1.992 & 1.26 & 1 & 5 & 6573 \\
OBST_LEGAL & 1.622 & 1.25 & 0 & 4 & 6504 \\
OBST_LABOR & 1.625 & 1.37 & 0 & 4 & 6369 \\
& 1.723 & 1.21 & 0 & 4 & 6549 \\
\hline
\end{tabular}

Table 3: Correlation coefficients

\begin{tabular}{|c|c|c|c|c|c|c|c|c|c|c|c|c|}
\hline & $\begin{array}{c}\text { GROU } \\
P\end{array}$ & INNO & SIZE & AGE & ICT & $\begin{array}{c}\text { QUALIT } \\
\mathrm{Y}\end{array}$ & $\begin{array}{l}\text { EDU } \\
\text { C }\end{array}$ & $\begin{array}{l}\text { DIVERS } \\
\text { IF }\end{array}$ & $\begin{array}{c}\text { URBA } \\
\mathrm{N}\end{array}$ & $\begin{array}{c}\text { OBST }_{-} \\
\text {FINANC } \\
\text { E }\end{array}$ & $\begin{array}{l}\mathrm{OBST}_{-} \\
\text {LEGAL }\end{array}$ & $\begin{array}{l}\mathrm{OBST}_{-} \\
\mathrm{LABOR}\end{array}$ \\
\hline GAF & 1.000 & & & & & & & & & & & \\
\hline INNO & 0.096 & 1.000 & & & & & & & & & & \\
\hline SIZE & 0.145 & 0.241 & 1.000 & & & & & & & & & \\
\hline AGE & 0.089 & 0.099 & 0.247 & 1.000 & & & & & & & & \\
\hline ICT & 0.099 & 0.243 & 0.294 & 0.096 & 1.000 & & & & & & & \\
\hline QUALITY & 0.109 & 0.252 & 0.380 & 0.183 & 0.180 & 1.000 & & & & & & \\
\hline EDUC & 0.067 & 0.064 & 0.048 & 0.036 & 0.073 & 0.099 & 1.000 & & & & & \\
\hline DIVERSIF & 0.053 & 0.141 & 0.085 & 0.133 & 0.095 & 0.084 & 0.053 & 1.000 & & & & \\
\hline URBAN & 0.018 & 0.023 & $\begin{array}{l}- \\
0.077\end{array}$ & $\overline{-} .004$ & $\begin{array}{l}- \\
0.048\end{array}$ & 0.020 & $\overline{-}-035$ & $\begin{array}{c}- \\
0.023\end{array}$ & 1.000 & & & \\
\hline $\begin{array}{c}\text { OBST_FIN } \\
\text { ANCE }\end{array}$ & 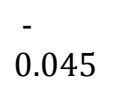 & 0.006 & $\begin{array}{l}- \\
0.112\end{array}$ & 0.083 & $\begin{array}{l}- \\
0.024\end{array}$ & 0.096 & $-\overline{0}$ & 0.003 & 0.051 & 1.000 & & \\
\hline $\begin{array}{c}\text { OBST_LE } \\
\text { GAL }\end{array}$ & 0.024 & 0.007 & 0.053 & 0.005 & 0.028 & 0.019 & $-\overline{0}$ & 0.039 & 0.010 & 0.243 & 1.000 & \\
\hline $\begin{array}{c}\text { OBST_LA } \\
\text { BOR }\end{array}$ & 0.038 & 0.112 & 0.079 & 0.083 & 0.118 & 0.027 & 0.000 & 0.061 & 0.037 & 0.266 & 0.384 & 1.000 \\
\hline
\end{tabular}




\section{Econometric model and methods}

The econometric analysis seeks to estimate the relationship between group affiliation (GAF dummy) and firms' innovation (INNO dummy), and how this relationship is affected by country-specific institutional factors (financial, legal and labor market institutions). As noted in previous research, one main issue that arises in this context is that some firm-specific characteristics (measured or unobservable) may affect both the probability that a firm is a GAF and its performance. Khanna (2000: 752) calls this issue "winner picking": if a firm has a successful performance, it is more likely that it will be invited to join a business group. A similar issue may arise in our study. Some firmspecific characteristics may in principle affect both the probability that a firm is selected to take part in a group and its ability or propensity to innovate. If this is the case, a problem of selection bias arises, due to the fact that firms self-select into two different categories, GAFs and SAFs, and this will affect the estimation of the group-innovation relationship.

In order to properly take account of this issue, we use a two-equation approach and model both the probability that an enterprise is a GAF (equation 1) and its innovation propensity (equation 2). The first equation studies the factors that may determine why a firm is selected to take part in a group, whereas the second equation estimates the determinants of its innovation propensity. These two equations form a recursive system of equations, since the dependent variable in equation 1 (GAF dummy) is included among the explanatory variables in equation 2 . The full model specification is the following:

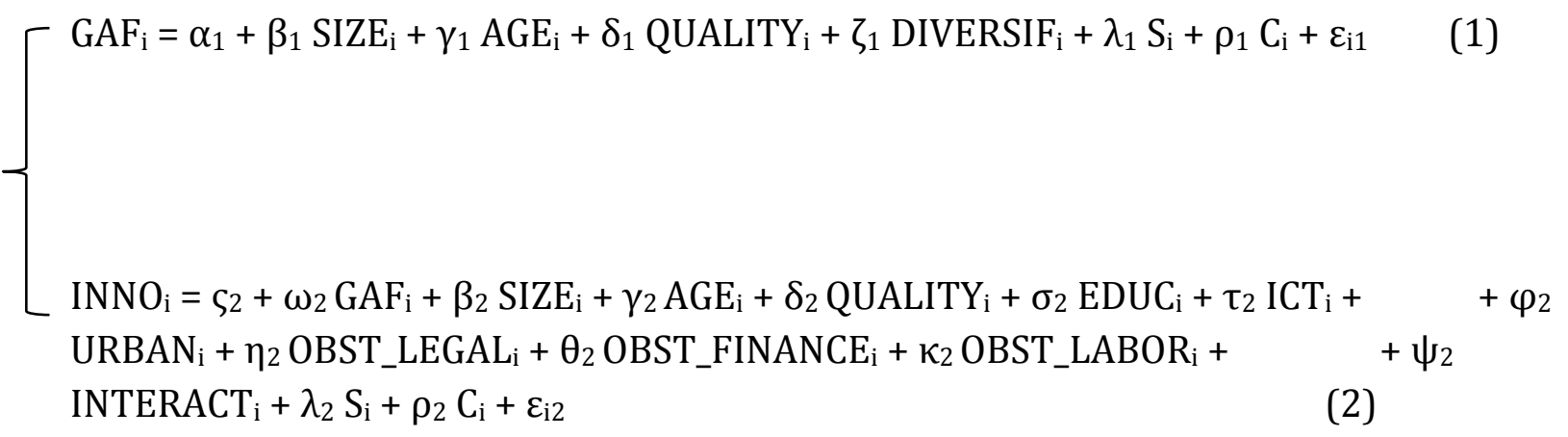

The explanatory variables include group affiliation plus a set of firm-level characteristics (size, age, quality, product diversification, education level, ICT infrastructures, urban density), some interaction variables (defined below), and the full set of sector and country dummies ( $S_{i}$ and $C_{i}$ respectively).

The GAF variable in equation 2 is expected to be positive: in line with previous research, we postulate that GAFs have higher innovation propensity than SAFs. All the firmspecific control variables are also expected to take a positive sign in the estimations: the firm's probability to be part of a group (equation 1) and its innovation propensity (equation 2) are assumed to be positively related to the enterprise's size, age, product quality, degree of product diversification, human capital, ICT infrastructures, and 
geographical (urban) location. Further, in line with previous analyses based on firmlevel survey data, we also expect the three variables OBST_FINANCE, OBST_LEGAL and OBST_LABOR to take a positive sign in the estimations, indicating that financial legal and labor market institutions are regarded by firms as important factors shaping their business activities.

In order to test hypotheses 1, 2 and 3, which compare the predictions of the institutional voids thesis (H1a, H2a, H3a) and the entry barriers thesis (H1b, H2b, H3b), we make use of the six country-level indicators defined in the previous section. Specifically, we introduce some interaction terms in equation 2 , in order to investigate how financial institutions (FINANCE, STOCK), legal institutions (LEGAL, TRUST) and labor market regulations (LABOR, TERTIARY) affect the affiliation-innovation relationship. These interaction variables are constructed as follows. First, for each of these institutional variables, we carried out a hierarchical cluster analysis and divided the 20 countries in the sample into two groups: those whose institutional system is above average (wellfunctioning institutions) and those below average (weak and inefficient institutions). Next, we created two interaction variables for each institutional indicator, one multiplying the GAF dummy and the "above average" country group dummy, and the other between GAF and the "below average" country group dummy. These interaction variables test hypotheses 1,2 and 3 by estimating a piecewise linear relationship between GAF and INNO. If the estimated coefficients for the "good institutions" interaction variables turn out to be higher (lower) than those for the "bad institutions" variables, this would provide evidence in favor of the entry barriers (institutional voids) thesis, because it would indicate that the positive effect of group affiliation on innovation is stronger in countries with a better (worse) institutional quality. ${ }^{7}$

As noted above, one important econometric issue that arises in the estimation of this model is so-called self-selection into categories: firms self-select into two different categories, GAFs and SAFs, and this is likely to affect the estimation of the groupinnovation relationship. Since firm-specific characteristics may affect both the probability that a firm is selected to take part in a group and its innovation propensity, the variable GAF in equation 2 is likely to be correlated with the error term, and its estimated elasticity does arguably overestimate the effect of group affiliation on innovation. Our strategy to cope with this issue is twofold.

First, we use propensity score matching (PSM) estimations. The basic idea of the matching approach is to select a group of SAFs firms in the sample which are as similar as possible to the corresponding group of GAFs (conditional on a set of firm-level characteristics). By comparing (matching) the two groups of enterprises, it is possible to

\footnotetext{
${ }^{7}$ A recent debate in the applied econometrics literature discusses the use and interpretation of interaction terms in non-linear models such as logit and probit. Ai and Norton (2003) opened this debate and criticized the common interpretation of interaction terms in non-linear models. Greene (2010) and Kolasinski and Siegel (2010) have recently responded to this criticism and shown that the usual interpretation of interaction effects is reasonable and more informative than the method proposed by Ai and Norton.
} 
obtain an unbiased estimate of the effect of group affiliation on innovation (Caliendo and Kopeinig, 2008; Reeb et al., 2012).

The PSM method proceeds in three steps. First, it estimates the probability that a firm is a GAF, using as covariates variables that affect both the GAF dummy and the innovation dummy. This is a simple probit estimation of equation 1 . Secondly, it creates two similar groups of firms, GAFs and SAFs, based on the propensity score obtained in the first step. Thirdly, it compares the mean of the two groups. This estimated difference (so-called average treatment effect on the treated, ATT) provides an unbiased estimate of the effect of group affiliation on innovation propensity.

The second approach we use is to estimate equations 1 and 2 through a recursive bivariate probit method, in which both equations are simultaneously estimated and the endogeneity of the GAF variable in equation 2 is properly handled by the way the model is estimated. The recursive bivariate probit is a seemingly unrelated regression model with correlated disturbances, in which the dependent variable of the first equation appears on the righ-hand-side of the second equation. The model is estimated by MLE. Greene (2003: 715-716) points out that in such a model the endogeneity of one of the RHS variables of the second equation can be neglected because this term does not affect the maximization of the log-likelihood (differently from what it would be the case in a linear recursive model not estimated by MLE).

\section{Results}

We first present the results of propensity score matching (tables 4 and 5), and then the estimations of our two-equation system through the recursive bivariate probit model (table 6). As explained in the previous section, the PSM method selects a group of SAFs in the sample which are as similar as possible to the corresponding group of GAFs (conditional on a set of firm-level characteristics) and, by comparing the two groups of enterprises, it provides an unbiased estimate of the effect of group affiliation on innovation.

Table 4 presents the PSM results for the whole sample. We compare four sets of results: for two different model specifications and for two different matching methods (Knearest neighbors and kernel matching). These four sets of results are closely in line with each other. After creating two similar groups of firms (GAFs versus SAFs), conditional on the set of firm-level characteristics outlined in equation 2, a comparison of the two indicates that GAFs have on average an innovation propensity of nearly $59 \%$, whereas the mean for the SAF control group is around $50 \%$. The difference between the two (the ATT, i.e. the average treatment effect on the treated) is around $9 \%$. This is our unbiased estimate of the effect of group affiliation on innovation propensity. These results indicate that in Latin America the innovation propensity of GAFs is on average 
$9 \%$ higher than that of SAFs. ${ }^{8}$ On the whole, the PSM results are in line with, and corroborate further, the findings of recent research on the innovativeness of business groups in East Asia (Mahmood and Mitchell, 2004; Mahmood and Lee, 2004; Chang et al., 2006; Mahmood et al., 2011) and Europe (Belenzon and Berkovitz, 2010). Table 5 reports the estimated ATT for each country. These indicate that, although the effect of group affiliation on innovation is positive for most Latin American economies in the sample, the cross-country variability of this estimated effect is substantial. It is therefore important to investigate to what extent these cross-country differences may be explained by the different institutional conditions that characterize Latin American economies.

Table 4: Propensity score matching (PSM): estimation results for the whole sample.

\begin{tabular}{|c|c|c|c|c|}
\hline \multirow[b]{2}{*}{ Matching method } & \multicolumn{2}{|c|}{$\begin{array}{l}\text { Basic model specification } \\
\text { (as in equation 1) }\end{array}$} & \multicolumn{2}{|c|}{ Extended model specification ${ }^{a}$} \\
\hline & $\begin{array}{l}\text { K-nearest } \\
\text { neighbors }\end{array}$ & Kernel & $\begin{array}{l}\text { K-nearest } \\
\text { neighbors }\end{array}$ & Kernel \\
\hline $\begin{array}{l}\text { Average GAF } \\
\text { (treated) }\end{array}$ & 0.584 & 0.584 & 0.589 & 0.589 \\
\hline $\begin{array}{l}\text { Average SAF } \\
\text { (controls) }\end{array}$ & 0.498 & 0.495 & 0.509 & 0.496 \\
\hline $\begin{array}{l}\text { Difference } \\
\text { (ATT) }\end{array}$ & 0.086 & 0.089 & 0.080 & 0.093 \\
\hline $\begin{array}{l}\text { Standard } \\
\text { error }\end{array}$ & $0.020^{* * *}$ & $0.020^{* * *}$ & $0.021^{* * *}$ & $0.020^{* * *}$ \\
\hline $\begin{array}{l}\text { Number of GAF } \\
\text { (treated) }\end{array}$ & 756 & 756 & 733 & 733 \\
\hline $\begin{array}{l}\text { Number of SAF } \\
\text { (controls) }\end{array}$ & 5375 & 5375 & 5146 & 5146 \\
\hline $\begin{array}{c}\text { Mean bias: } \\
\text { Before matching }\end{array}$ & $16.2 \%$ & $16.2 \%$ & $15.6 \%$ & $15.6 \%$ \\
\hline $\begin{array}{c}\text { Mean bias: } \\
\text { After matching }\end{array}$ & $2.2 \%$ & $2.7 \%$ & $3.3 \%$ & $3.4 \%$ \\
\hline
\end{tabular}

a The extended model specification also includes the variables OBST_FINANCE, OBST_LEGAL and OBST_LABOR in equation 1. Legend: GAF: group-affiliated firms; SAF: Standalone firms; ATT: average treatment effect on the treated

\footnotetext{
${ }^{8}$ We have also repeated the same PSM exercise with a different dependent variable, in order to test whether these results also hold for the indicator "NEW_PROD" (a dummy variable indicating whether the firm has introduced a new product in the period). The results for this innovation outcome variable are closely in line with those for the R\&D variable: the estimated ATT is in the range between 8.6 and $9.3 \%$. Therefore, our main result that GAFs are more innovative than SAFs does not only hold for the innovative propensity of firms, but it does also extend to their technological performance.
} 
Table 5: PSM results by country: estimated ATT (average treatment effect on the treated) for each country.

\begin{tabular}{|cccc|}
\hline & $\begin{array}{c}\text { Matching method: K- } \\
\text { nearest neighbors }\end{array}$ & $\begin{array}{c}\text { Matching method: } \\
\text { Kernel }\end{array}$ & Observations \\
Argentina & 0.066 & 0.063 & \\
Bolivia & 0.020 & 0.022 & 791 \\
Chile & 0.029 & 0.046 & 120 \\
Colombia & 0.040 & 0.131 & 775 \\
Costa Rica & 0.137 & 0.157 & 705 \\
Dominican Republic & -0.250 & -0.285 & 326 \\
Ecuador & -0.077 & -0.158 & 122 \\
El Salvador & 0.028 & 0.020 & 120 \\
Guatemala & 0.000 & 0.002 & 125 \\
Honduras & 0.208 & 0.230 & 355 \\
Jamaica & 0.450 & 0.481 & 150 \\
Mexico & 0.120 & 0.136 & 121 \\
Nicaragua & 0.014 & -0.031 & 1152 \\
Panama & 0.062 & 0.084 & 126 \\
Peru & 0.098 & 0.090 & 115 \\
Suriname & 0.500 & 0.500 & 760 \\
Uruguay & 0.060 & 0.039 & 75 \\
Venezuela & 0.075 & 0.089 & 360 \\
& & & 85 \\
\hline
\end{tabular}

We then shift the focus to the results of the estimations of our two-equation system through the recursive bivariate probit model. Equation 2 is the specification of our main interest, investigating the determinants of firms' innovation propensity and providing tests of the three hypotheses on the role of financial, legal and labor market institutions. On the other hand, the estimation of equation 1, investigating the determinants of the probability that a firm is a GAF, simply represents a first stage in the econometric analysis but does not provide any direct information on the hypotheses of our interest. We therefore report these results in the Appendix table A1, but will not comment them further here.

Table 6 reports the results of the estimation of equation 2. Before discussing the results of the hypotheses tests, it is interesting to look at the estimates for the firm-specific (control) variables included in equation 2. As expected, most of the firm-level control factors matter for the innovativeness of enterprises in Latin America. Firms are more likely to be innovators the greater their size, product quality and ICT infrastructure. Innovation propensity is also positively related to the size of the urban location in which firms are located, reflecting urban density and agglomeration economies. Differently from our expectations, two firm-level characteristics are not significantly related to the R\&D dummy. Firm age and human capital level (number of education years of full-time permanent employees) do not turn out to have a significant effect on the probability that an enterprise undertakes R\&D investments. 
Next, the variables OBST_FINANCE, OBST_LEGAL and OBST_LABOR are as expected all positively and significantly related to the innovation dummy dependent variable. This indicates that Latin American firms, on average, regard national institutions (financial, legal and labor market) as important factors supporting their innovative activities. In particular, OBST_LABOR is the factor that turns out to have the strongest estimated coefficient, providing evidence that extensive and inefficient labor market regulations that characterize many countries in Latin America are perceived by business firms as an important obstacle to their innovative activities (Botero et al., 2004; Schneider, 2009).

A key explanatory variable in equation 2 is the GAF dummy, which tests whether groupaffiliated firms are more innovative than standalone enterprises. In line with the results of propensity score matching estimations, this hypothesis receives support: the first column in table 6 shows that the estimated coefficient of the GAF dummy is positive and significant.

We then shift the focus to the results of the tests of our three main hypotheses, which investigate the cross-country predictions of the two competing views. In short, the three hypotheses investigate whether, across countries, the difference between the innovativeness of GAFs and SAFs is stronger in countries with weaker and less efficient financial, legal and labor market institutions, as implied by the institutional voids thesis, or rather in economies with a stronger and more reliable institutional set up, as expected by the entry barriers thesis. This set of propositions are tested in regressions 2 to 7, which make use of a piecewise linear specification in which the GAF coefficient is allowed to differ across two country groups: one characterized by stronger and more efficient financial, legal and labor market institutions, and the other with a weaker and less efficient institutional set up (see the previous section for a definition of the interaction variables that are inserted in regressions 2 to 7).

Columns 2 and 3 report the results of the test of hypothesis 1 on the role of financial institutions. The interaction variables in these regressions are both positive, and the size of the coefficient for the "good institution" cluster is higher than that for the "bad institution" country group, particularly for the STOCK indicator. This would suggest that the effect of group affiliation on innovation is stronger for countries with a better financial system than for economies characterized by weaker financial infrastructures.

Hypothesis 2, referring to legal institutions, is tested in regressions 4 and 5. The results for the indicator LEGAL is in line with the prediction of the entry barriers view, but the difference between the good and the bad institutions country groups is small and not significant. By contrast, the results for the TRUST indicator (column 5) are sharper and more precise, and indicate that group affiliation has a stronger effect on firms' innovativeness in economies characterized by low levels of trust, weak legal institutions and higher transaction costs, in line with the predictions of the institutional voids thesis.

Columns 6 and 7 shift the focus to the role of labor market institutions (hypothesis 3). The results are mixed and non-conclusive: the regressions including the LABOR 
interaction variable provide support for the entry barriers view, whereas those for the TERTIARY interaction variable are more in line with the prediction of the institutional voids thesis. However, in both regressions the difference between the good and the bad institutions country groups is small and not significant, so that further empirical evidence is necessary to shed light on this point.

Table 6: Estimation results for equation 2. Dependent variable: INNO. Estimation method: recursive bivariate probit.

\begin{tabular}{|c|c|c|c|c|c|c|c|}
\hline & (1) & (2) & (3) & (4) & (5) & (6) & (7) \\
\hline Hypotheses tested & $\begin{array}{l}\text { Basic } \\
\text { model }\end{array}$ & H1 & H1 & $\mathrm{H} 2$ & $\mathrm{H} 2$ & $\mathrm{H} 3$ & $\mathrm{H} 3$ \\
\hline $\begin{array}{l}\text { Institutional } \\
\text { variable }\end{array}$ & - & FINANCE & STOCK & LEGAL & TRUST & LABOR & TERTIARY \\
\hline GAF & $\begin{array}{c}0.629 \\
(1.83)^{*}\end{array}$ & & & & & & \\
\hline GAF * GOOD & & 0.640 & 0.581 & 0.678 & 0.536 & 0.678 & 0.625 \\
\hline INSTITUTIONS & & $(1.84)^{*}$ & $(1.54)$ & $(1.88)^{*}$ & (1.51) & $(1.88)^{*}$ & $(1.86)^{*}$ \\
\hline GAF * BAD & & 0.618 & 0.478 & 0.631 & 0.669 & 0.631 & 0.682 \\
\hline INSTITUTIONS & & $(1.77)^{*}$ & (1.12) & $(1.86)^{*}$ & $(1.95)^{*}$ & $(1.86)^{*}$ & $(1.96)^{* *}$ \\
\hline SIZE & $\begin{array}{c}0.236 \\
(7.28)^{* * *}\end{array}$ & $\begin{array}{c}0.236 \\
(7.28)^{* * *}\end{array}$ & $\begin{array}{c}0.240 \\
(7.19)^{* * *}\end{array}$ & $\begin{array}{c}0.235 \\
(7.25)^{* * *}\end{array}$ & $\begin{array}{c}0.236 \\
(7.27)^{* * *}\end{array}$ & $\begin{array}{c}0.235 \\
(7.25)^{* * *}\end{array}$ & $\begin{array}{c}0.235 \\
(7.25)^{* * *}\end{array}$ \\
\hline AGE & $\begin{array}{r}-0.000 \\
(0.29)\end{array}$ & $\begin{array}{l}-0.000 \\
(0.28)\end{array}$ & $\begin{array}{c}-0.000 \\
(0.26)\end{array}$ & $\begin{array}{r}-0.000 \\
(0.28)\end{array}$ & $\begin{array}{r}-0.000 \\
(0.32)\end{array}$ & $\begin{array}{r}-0.000 \\
(0.28)\end{array}$ & $\begin{array}{c}-0.000 \\
(0.31)\end{array}$ \\
\hline ICT & $\begin{array}{c}0.709 \\
(10.53)^{* * *}\end{array}$ & $\begin{array}{c}0.709 \\
(10.53)^{* * *}\end{array}$ & $\begin{array}{c}0.711 \\
(10.54)^{* * *}\end{array}$ & $\begin{array}{c}0.709 \\
(10.52)^{* * *}\end{array}$ & $\begin{array}{c}0.710 \\
(10.54)^{* * *}\end{array}$ & $\begin{array}{c}0.709 \\
(10.52)^{* * *}\end{array}$ & $\begin{array}{c}0.709 \\
(10.52)^{* * *}\end{array}$ \\
\hline QUALITY & $\begin{array}{c}0.372 \\
(7.57)^{* * *}\end{array}$ & $\begin{array}{c}0.372 \\
(7.57)^{* * *}\end{array}$ & $\begin{array}{c}0.375 \\
(7.59)^{* * *}\end{array}$ & $\begin{array}{c}0.371 \\
(7.53)^{* * *}\end{array}$ & $\begin{array}{c}0.373 \\
(7.59)^{* * *}\end{array}$ & $\begin{array}{c}0.371 \\
(7.53)^{* * *}\end{array}$ & $\begin{array}{c}0.370 \\
(7.54)^{* * *}\end{array}$ \\
\hline EDUC & $\begin{array}{l}0.003 \\
(0.67)\end{array}$ & $\begin{array}{l}0.003 \\
(0.67)\end{array}$ & $\begin{array}{l}0.003 \\
(0.66)\end{array}$ & $\begin{array}{l}0.003 \\
(0.67)\end{array}$ & $\begin{array}{l}0.003 \\
(0.65)\end{array}$ & $\begin{array}{l}0.003 \\
(0.67)\end{array}$ & $\begin{array}{l}0.003 \\
(0.65)\end{array}$ \\
\hline URBAN & $\begin{array}{c}0.047 \\
(2.65)^{* * *}\end{array}$ & $\begin{array}{c}0.047 \\
(2.63)^{* * *}\end{array}$ & $\begin{array}{c}0.047 \\
(2.63)^{* * *}\end{array}$ & $\begin{array}{c}0.046 \\
(2.63)^{* * *}\end{array}$ & $\begin{array}{c}0.048 \\
(2.69)^{* * *}\end{array}$ & $\begin{array}{c}0.046 \\
(2.63)^{* * *}\end{array}$ & $\begin{array}{c}0.047 \\
(2.64)^{* * *}\end{array}$ \\
\hline OBST_FINANCE & $\begin{array}{l}0.023 \\
(1.50)\end{array}$ & $\begin{array}{c}0.0239 \\
(1.50)\end{array}$ & $\begin{array}{l}0.024 \\
(1.51)\end{array}$ & $\begin{array}{l}0.024 \\
(1.51)\end{array}$ & $\begin{array}{l}0.024 \\
(1.48)\end{array}$ & $\begin{array}{c}0.024 \\
(1.51)\end{array}$ & $\begin{array}{c}0.023 \\
(1.49)\end{array}$ \\
\hline OBST_LEGAL & $\begin{array}{c}0.027 \\
(1.82)^{*}\end{array}$ & $\begin{array}{l}0.027 \\
(1.82)^{*}\end{array}$ & $\begin{array}{c}0.027 \\
(1.81)^{*}\end{array}$ & $\begin{array}{c}0.027 \\
(1.82)^{*}\end{array}$ & $\begin{array}{l}0.027 \\
(1.80)^{*}\end{array}$ & $\begin{array}{c}0.027 \\
(1.82)^{*}\end{array}$ & $\begin{array}{c}0.027 \\
(1.82)^{*}\end{array}$ \\
\hline OBST_LABOR & $\begin{array}{c}0.049 \\
(2.84)^{* * *}\end{array}$ & $\begin{array}{c}0.049 \\
(2.83)^{* * *}\end{array}$ & $\begin{array}{c}0.050 \\
(2.84)^{* * *}\end{array}$ & $\begin{array}{c}0.049 \\
(2.83)^{* * *}\end{array}$ & $\begin{array}{c}0.049 \\
(2.84)^{* * *}\end{array}$ & $\begin{array}{c}0.049 \\
(2.83)^{* * *}\end{array}$ & $\begin{array}{c}0.049 \\
(2.83)^{* * *}\end{array}$ \\
\hline $\begin{array}{c}\chi^{2} \text { (Test of } \\
\text { difference } \\
\text { between } \\
\text { good and bad } \\
\text { institutions) }\end{array}$ & - & 0.04 & 0.57 & 0.15 & 1.22 & 0.15 & 0.28 \\
\hline
\end{tabular}

All regressions are run on a sample of 5466 observations, and include industry dummies and country dummies.

We then carry out another exercise in order to shed further light on the role of national institutions for the innovativeness of business groups, making use of aggregate (country-level) data. Table 7 reports the coefficients of correlation (Spearman's rank 
correlation) between the estimated ATT parameters for each country (see table 5 above) and country-specific institutional conditions across the Latin American region. As explained above, the ATT parameters provide an unbiased estimate of the difference between the innovativeness of GAFs and SAFs. So, the correlation between these parameters and countries' institutional conditions may be seen as a direct test of the contrasting predictions of the institutional voids versus the entry barriers thesis: a positive (negative) correlation coefficient would indicate that, across countries in Latin America, group affiliation spurs innovation relatively more in economies with a stronger (weaker) institutional set up - providing evidence in favor of the entry barriers (institutional voids) view.

The results in table 7 indicate different patterns for the three hypotheses under investigation. For hypothesis 1 (financial institutions), the results are mixed and depend on the indicator that it is used to measure country-specific financial conditions. In general terms, better access to finance (FINANCE) decreases the innovativeness of GAFs vis-à-vis SAFs, as postulated by the institutional voids thesis. However, the availability of equity finance through the stock market (STOCK) tends to strengthen the innovation performance of affiliated companies. According to the entry barriers view, equity finance may spur innovation investments because it contributes to lower the risks of uncertain technological activities, and it increases the financial commitment of the enterprise. If GAFs, thanks to their group affiliation, have a higher facility and propensity to use equity finance than SAFs, this may increase the financial resources that they invest in innovative activities vis-à-vis SAFs.

The results of the test of hypothesis 2 (legal institutions) are in line with the regression table discussed above, and provide evidence in favour of the institutional voids thesis, given the high and significant positive correlation between the TRUST indicator and the estimated GAF's innovativeness. By contrast, the correlation coefficient for the LEGAL indicator is close to zero and weakly significant. In line with previous research, the interpretation of the results for this second hypothesis is that business groups, thanks to their organizational structure and internal networks, may make up for the lack of wellfunctioning legal institutions and partly avoid weak contract enforcement issues, thus making it possible to decrease transaction costs in emerging markets. Group affiliation does for this reason represent a more important factor spurring innovative activities in countries with weaker and less efficient legal institutions.

Finally, in relation to hypothesis 3 (labor market institutions), table 7 shows that the correlation between the indicators LABOR and TERTIARY and the estimated ATT parameters are both positive, and hence in line with the prediction of the entry barriers view. Across countries in Latin America, the difference between the innovativeness of GAFs and SAFs is stronger in national economies with better and more efficient labor market institutions. Our interpretation of this result is that, when labor markets become more efficient and flexible, it may become easier for GAFs to use this greater institutional flexibility to get rid of less productive workers and attract the most talented 
managers and employees, thus increasing their human capital level and innovative potential vis-a-vis SAFs. Hence, business groups may benefit from labor market liberalization to a greater extent than SAFs.

Table 7: Cross-country tests: Coefficients of correlation between GAFs' innovativeness (ATT from PSM estimations by country) and country-specific institutional conditions.

\begin{tabular}{|ccccc|}
\hline Institutions & Variable & $\begin{array}{c}\text { Spearman's rank } \\
\text { correlation }\end{array}$ & $\begin{array}{c}\text { Supported } \\
\text { hypothesis }\end{array}$ & Supported thesis \\
Financial & FINANCE & -0.391 & H1a & IV \\
& STOCK & +0.357 & H1b & EB \\
Legal & LEGAL & +0.055 & H2b & EB \\
& TRUST & -0.573 & H2a & IV \\
& LABOR & +0.092 & H3b & EB \\
Labor market & TERTIARY & +0.143 & H3b & EB \\
\hline
\end{tabular}

Legend: IV: Institutional voids thesis; EB: Entry barriers thesis

\section{Discussion and conclusions}

The paper has carried out an empirical analysis of the innovative activities of business groups in Latin America. The study has compared the innovativeness of group-affiliated firms and standalone enterprises, and it has investigated how country-specific institutional factors - financial, legal, and labor market institutions - affect the groupinnovation relationship. The empirical analysis has made use of the extensive dataset made available by the most recent wave of the WBES (period 2010-2011), providing a rich set of information on 6500 manufacturing firms in 20 Latin American countries. The econometric results point out two major conclusions, which we summarize here along with a brief discussion of their policy implications.

The first main conclusion is that GAFs are more innovative than SAFs. After controlling for a large set of firm- and country-specific characteristics, and correcting for the possible self-selection bias due to the winner-picking mechanism, our econometric analysis estimates that the innovation propensity of GAFs is about $9 \%$ higher than that for SAFs. The result of a positive effect of group affiliation on innovation is in line with the few empirical studies analyzing this topic for the case of East Asian economies (Mahmood and Mitchell, 2004; Mahmood and Lee, 2004; Chang et al., 2006; Mahmood et al., 2011) and European countries (Belenzon and Berkovitz, 2010). 
An implication of this result is that, by fostering the technological dynamics of the national system in which they operate, business groups have an important welfareenhancing function in emerging economies, since they contribute to the process of domestic capability building and economic transformation through knowledge spillovers. At the same time, however, this also implies that standalone firms, which represent a great majority of the business population in Latin America, are losing ground and progressively becoming less competitive than the relatively small number of business groups that dominate domestic markets in these emerging economies. This type of diverging dynamics may have negative effects on the income distribution and further exacerbate income and social inequalities that do currently represent a major issue in Latin America. In order to counteract this diverging dynamics, national authorities should more systematically provide innovation policy support to standalone enterprises, targeting their technological capabilities, human capital as well as their access to financial capital and physical and ICT infrastructures.

The second main conclusion refers to the empirical test of the contrasting predictions of the institutional voids thesis, on the one hand, and the entry barriers view, on the other. Our results indicate that it is not possible to conclude in favor of one of them only and rejecting the other, since both theses receive some support in our empirical analysis. Specifically, we find that, across countries in Latin America, the superior innovation performance of GAFs is stronger for national economies with weaker legal institutions (as predicted by the institutional voids thesis), and for countries with more efficient labor market regulations (as postulated by the entry barriers thesis). Regarding financial institutions, the results are mixed, indicating that in general better access to finance decreases the innovativeness of GAFs vis-à-vis SAFs, but also that the availability of equity finance through the stock market tends to strengthen the innovation performance of affiliated companies.

In short, while it is true that GAFs may have strong internal capabilities, resources and networks, and hence partly make up for weak or inefficient institutions as pointed out by the institutional voids thesis, we also find that group innovativeness tends to increase when market institutions become more efficient, in line with the main prediction of the entry barriers thesis. The paper does therefore not provide a conclusive answer to the question of how the relationship between group affiliation and innovation varies across countries, and opens up the way for further research in the future.

Regarding the process of market development, a general implication of our results is that institutional changes and economic reforms intended to make domestic markets more open, competitive and efficient - such as the extensive wave of privatizations, trade liberalization, financial and macroeconomic stabilization undertaken in many Latin American countries during the 1980s and 1990s - do not necessarily drive business groups out of the market. By contrast, the effect of institutional changes and market liberalization is often that business groups, by exploiting their superior capabilities and dominant market position, are able to develop new strategies and find 
new market niches, whereas smaller standalone firms are more likely to loose market shares and shrink. The Latin American case analyzed in this paper suggests that, when focusing on business groups innovation activities, a process of creative destruction is in place, according to which larger and well established domestic firms survive, adapt and innovate, whereas smaller and less competitive enterprises are eventually driven out of the market. This evolutionary process - driven by competition, selection and innovation - is a major driver of business dynamics in contemporary Latin America.

\section{Acknowledgments}

This article is produced as part of the project "Confronting Transnationalization: The Economic, Environmental, and Political Strategies of Central American Economic Groups". Financial support from the Norwegian Research Council (Latin America programme) is gratefully acknowledged. The paper was presented at a seminar at the Norwegian Institute of International Affairs in August 2012, at the Centre for Development and the Environment (University of Oslo) in September 2012, at SPRU (Science and Technology Policy Research, University of Sussex, UK) in January 2013, and Copenhagen Business School (Denmark) in February 2013. I wish to thank Benedicte Bull, Tommaso Ciarli, Aimee Gonzalez Ferriol, Aleksandra Gregorič, Barbara Hogenboom, Yuri Kasahara, Jorge Mario Martinez, Will Mitchell, Maria Savona, and Gaaitzen de Vries for the very useful comments and suggestions on a previous draft of the paper. 


\section{References}

Aghion, P., N. Bloom, R. Blundell, R. Griffith and P. Howitt (2005): "Competition and innovation: an inverted U relationship", Quarterly Journal of Economics, 120 (2): 701-728.

Ai, C. and Norton, E. (2003): "Interaction terms in logit and probit models", Economics Letters, 80: 123-129.

Aldrighi and Postali (2010): "Business groups in Brazil", in Colpan, A., Hikino, T. and Lincoln, J. (Eds.): The Oxford Handbook of Business Groups, Oxford University Press, Oxford.

Belenzon, S. and Berkovitz, T. (2010): "Innovation in business groups", Management Science, 56 (3): 519-535.

Belloc, F. (2012): "Corporate governance and innovation: a survey", Journal of Economic Surveys, 26 (5): 835-864.

Botero, J., Djankov, S., La Porta, R., Lopez-de-Silanes, F. and Shleifer, A. (2004): “The regulation of labor", Quarterly Journal of Economics, 119 (4): 1339-1382.

Bull, B. and Kasahara, Y. (2012): "The dominating diversified business groups in Central America: Who are they and where are they heading?", SUM, University of Oslo, mimeo.

Caliendo, M. and Kopeinig, S. (2008): "Some practical guidance for the implementation of propensity score matching", Journal of Economic Surveys, 22, 1: 31-72.

Carney, M., Gedajlovic, E., Heugens, P., Van Essen, M. and Van Oosterhout, J. (2011): "Business group affiliation, performance, context, and strategy: a meta-analysis", Academy of Management Journal, 54 (3): 437-460.

Castellacci, F. (2007): “Evolutionary and new growth theories. Are they converging?", Journal of Economic Surveys, 21 (3): 585-627.

Castellacci, F. (2011): “Closing the technology gap?", Review of Development Economics, 15 (1): 180-197.

Castellacci, F. and Archibugi, D. (2008): "The technology-clubs: The Distribution of Knowledge Across Nations", Research Policy, 37: 1659-1673.

Castellacci, F. and Natera, J. M. (2013): "The dynamics of national innovation systems: a panel cointegration analysis of the coevolution between innovative capability and absorptive capacity", Research Policy, 42 (3): 579-594. 
Chakrabarti, A., Vidal, E. and Mitchell, W. (2011): "Business transformation in heterogeneous environments: the impact of market development and firm strength on retrenchment and growth reconfiguration", Global Strategy Journal, 1: 6-26.

Chang, S. J., Chung, C. N. and Mahmood, I. P. (2006): "When and how does business group affiliation promote firm innovation? A tale of two emerging economies", Organization Science, 17 (5): 637-656.

Chari, M. and David, P. (2012): "Sustaining superior performance in an emerging economy: An empirical test in the Indian context", Strateguc Management Journal, 33: 217-229.

Chung, C., Mahmood, I. and Mitchell, W. (2007): "Political connections and business strategy: the impact of types and destinations of political ties on business diversification in closed and open political economic contexts", mimeo.

Cohen, W.M. and D.A. Levinthal (1990): "Absorptive capacity: a new perspective on learning and innovation", Administrative Science Quarterly, 35: 128-152.

Colpan, A., Hikino, T. and Lincoln, J. (2010): The Oxford Handbook of Business Groups, Oxford University Press, Oxford.

Cuervo-Cazzura, A. and Dau, L. A. (2009): "Promarket reforms and firm profitability in developing countries", Academy of Mangement Journal, 52 (6): 1348-1368.

Fogel, K. (2006): "Oligarchic family control, social economic outcomes, and the quality of government”, Journal of International Business Studies, 37 (5): 603-622.

Fortune, A. and Mitchell, W. (2012): "Unpacking firm exit at the firm and industry levels: the adaptation and selection of firm capabilities", Strategic Management Journal, 33: 794-819.

Foss, K. and Foss, N. (2005): "Resources and transaction costs: how property rights economics furthers the resource-based view", Strategic Management Journal, 26: 541-553.

Fracchia, E., Mesquita, L. and Quiroga, J. (2010): "Business groups in Argentina", in Colpan, A., Hikino, T. and Lincoln, J. (Eds.): The Oxford Handbook of Business Groups, Oxford University Press, Oxford.

Greene, W. (2003): Econometric Analysis, Fifth Edition, Upper Saddle River, N.J., Prentice Hall.

Greene, W. (2010): "Testing hypotheses about interaction terms in nonlinear models", Economics Letters, 107: 291-296.

Guillen, M. (2000): Business groups in emerging economies: A resource-based view", Academy of Management Journal, 43 (3): 362-380. 
Hall, P. and Soskice, D. (2001): Varieties of Capitalism: The Institutional Foundations of Comparative Advantage, Oxford University Press, New York.

Hannan, M. T. and Freeman, J. H. (1989): Organizational Ecology, Harvard University Press: Cambridge, MA.

Hoshino (2010): "Business groups in Mexico", in Colpan, A., Hikino, T. and Lincoln, J. (Eds.): The Oxford Handbook of Business Groups, Oxford University Press, Oxford.

Khanna, T. (2000): "Business groups and social welfare in emerging markets: Existing evidence and unanswered questions", European Economic Review, 44: 748-761.

Khanna, T. and Palepu, K. (1997): "Why focused strategies may be wrong for emerging markets", Harvard Business Review, 75 (4): 41-51.

Khanna, T. and Palepu, K. (2000): "The future of business groups in emerging markets: long-run evidence from Chile, Academy of Management Journal, 43 (3): 268-285.

Khanna, T. and Rivkin, J. W. (2001): "Estimating the performance effects of business groups in emerging markets", Strategic Management Journal, 22 (1): 45-74.

Khanna, T. and Rivkin, J. W. (2006): "Interorganizational ties and business group boundaries: evidence from an emerging economy", Organization Science, 17 (3): 333-352.

Khanna, T. and Yafeh, Y. (2005): "Business groups and risk sharing around the world”, The Journal of Business, 78 (1): 301-340.

Khanna, T. and Yafeh, Y. (2007): "Business groups in emerging markets: paragons or parasites", Journal of Economic Literature, XLV: 331-372.

Kolasinski, A. and Siegel, A. (2010): "On the economic meaning of interaction term coefficients in non-linear binary response regression models". SSRN paper. Available at SSRN: http://ssrn.com/abstract=1668750.

Lazonick, W. (2007): "The US stock market and the governance of innovative enterprise", Industrial and Corporate Change, 16 (6): 983-1035.

La Porta, R., Lopez-de-Silanes, F. and Shleifer, A. (1999): “Corporate ownership around the world", Journal of Finance, 54 (2): 471-517.

Leff, N. (1978): "Industrial organization and entrepreneurship in the developing countries: The economic groups", Economic Development and Cultural Change, 78: 661-674.

Mahmood, I. P. and Lee, C. Y. (2004): "Business groups: entry barrier-innovation debate revisited”, Journal of Economic Behavior and Organization, 54: 513-531. 
Mahmood, I. P. and Mitchell, W. (2004): "Two faces: Effects of business groups on innovation in emerging economies", Management Science, 50 (10): 1348-1365.

Mahmood, I., Zhu, H. and Zajac, E. (2011): "Where can capabilities come from? Network ties and capability acquisition in business groups", Strateguc Management Journal, 32: 820-848.

Mahmood, I., Chung, C. and Mitchell, W. (2012): "The evolving impact of combinatorial opportunities and exhaustion on innovation by business groups as market development increases: the case of Taiwan", Management Science, forthcoming.

Morck, R., Wolfenzon, D. and Yeung, B. (2005): "Corporate governance, economic entrenchment, and growth", Journal of Economic Literature, 43 (3): 655-720.

Nelson, R. R. (1993): National Innovation Systems: A Comparative Analysis, Oxford University Press, New York and Oxford.

Nelson, R.R. (1995): "Recent evolutionary theorizing about economic change”, Journal of Economic Literature, 33: 48-90.

Nelson, R. and Winter, S. (1982): An Evolutionary Theory of Economic Change, Belknap Press: Cambridge, MA.

Penrose, E. T. (1959): The Theory of the Growth of the Firm, Oxford University Press: Oxford, UK.

Rajan, R. and Zingales, L. (2003): "The great reversals: the politics of financial development in the 20th century", Journal of Financial Economics, 69 (1): 5-50.

Reeb, D., Sakakibara, M. and Mahmood, I. (2012): "Endogeneity in international business research", Journal of International Business Studies, 43: 211-218.

Schneider, B. R. (2009): "Hierarchical market economies and varieties of capitalism in Latin America", Journal of Latin American Studies, 41: 553-575.

Wernerfelt, B. (1984): “A resource-based view of the firm", Strategic Management Journal, 5 (2): 171-180.

Williamson, O. (1975): Market and Hierarchies: Analysis and Antitrust Implications, Free Press: New York. 


\section{Appendix}

Table A1: Estimation results for equation 1. Dependent variable: GAF. Estimation method: recursive bivariate probit.

\begin{tabular}{|c|c|c|c|c|c|}
\hline & (I) & (II) & (III) & (IV) & (V) \\
\hline SIZE & $\begin{array}{c}0.237 \\
(7.17)^{* * *}\end{array}$ & $\begin{array}{c}0.233 \\
(7.05)^{* * *}\end{array}$ & $\begin{array}{c}0.237 \\
(7.16)^{* * *}\end{array}$ & $\begin{array}{c}0.237 \\
(7.14)^{* * *}\end{array}$ & $\begin{array}{c}0.231 \\
(6.94)^{* * *}\end{array}$ \\
\hline AGE & $\begin{array}{c}0.002 \\
(1.74)^{*}\end{array}$ & $\begin{array}{c}0.002 \\
(1.68)^{*}\end{array}$ & $\begin{array}{c}0.002 \\
(1.74)^{*}\end{array}$ & $\begin{array}{c}0.002 \\
(1.74)^{*}\end{array}$ & $\begin{array}{l}0.002 \\
(1.64)\end{array}$ \\
\hline QUALITY & $\begin{array}{c}0.177 \\
(3.14)^{* * *}\end{array}$ & $\begin{array}{c}0.167 \\
(3.04)^{* * *}\end{array}$ & $\begin{array}{c}0.173 \\
(3.14)^{* * *}\end{array}$ & $\begin{array}{c}0.173 \\
(3.14)^{* * *}\end{array}$ & $\begin{array}{c}0.167 \\
(3.04)^{* * *}\end{array}$ \\
\hline DIVERSIF & $\begin{array}{c}-0.002 \\
(2.86)^{* * *}\end{array}$ & $\begin{array}{c}0.003 \\
(2.94)^{* * *}\end{array}$ & $\begin{array}{c}0.003 \\
(2.86)^{* * *}\end{array}$ & $\begin{array}{c}0.002 \\
(2.86)^{* * *}\end{array}$ & $\begin{array}{c}0.003 \\
(2.93)^{* * *}\end{array}$ \\
\hline OBST_FINANCE & & $\begin{array}{l}-0.037 \\
(1.90)^{*}\end{array}$ & & & $\begin{array}{c}-0.043 \\
(2.06)^{* *}\end{array}$ \\
\hline OBST_LEGAL & & & $\begin{array}{l}0.003 \\
(0.20)\end{array}$ & & $\begin{array}{l}0.010 \\
(0.55)\end{array}$ \\
\hline OBST_LABOR & & & & $\begin{array}{l}0.001 \\
(0.07)\end{array}$ & $\begin{array}{c}0.08 \\
(0.36)\end{array}$ \\
\hline $\begin{array}{l}\text { Industry } \\
\text { dummies }\end{array}$ & Yes & Yes & Yes & Yes & Yes \\
\hline $\begin{array}{l}\text { Country } \\
\text { dummies }\end{array}$ & Yes & Yes & Yes & Yes & Yes \\
\hline $\operatorname{LR} \chi^{2}$ & $1452.19^{* * *}$ & $1455.81^{* * *}$ & $1452.23^{* * *}$ & $1452.19^{* * *}$ & 1456.48 \\
\hline Observations & 5466 & 5466 & 5466 & 5466 & 5466 \\
\hline
\end{tabular}

The model in equation I is the basic specification corresponding to equation 1 . The regressions II to $\mathrm{V}$ are additional exercises including also the variables OBST_FINANCE, OBST_LEGAL and OBST_LABOR. 
Recent papers in the SPRU Working Paper Series:

SWPS 2013-01. Gabriele Pellegrino and Maria Savona. September 2013. "Is money all? Financing versus knowledge and demand constraints to innovations".

SWPS 2013-02. Adrian Smith and Sabine Hielscher. September 2013. "Grassroots digital fabrication and makerspaces: reconfiguring, relocating and recalibrating innovation".

SWPS 2013-03. Paul Nightingale and Alex Coad. September 2013. "Muppets and Gazelles: Political and Methodological Biases in Entrepreneurship Research".

SWPS 2013-04. Alberto Marzucchi and Sandro Montresor. September 2013. "The multidimensional additionality of innovation policies. A multi-level application to Italy and Spain". 